\title{
'Participation as planning': strategies from the South to challenge the limits of planning
}

\author{
Alexandre Apsan Frediani \& Camila Cociña
}

Suggested citations: Frediani, A. A., \& Cociña, C. (2019). 'Participation as planning': strategies from the South to challenge the limits of planning. Built Environment, 45(2).

\begin{abstract}
Participation and collaborative approaches to planning have become central in urban debates and practices. Critiques to the limitations of 'participation in planning', however, have led to the development of a series of approaches that build beyond 'collaborative' understandings of planning. Approaches such as insurgent or post-collaborative planning, movement-initiated co-production, socio-spatial learning, agonistic practices or participation as political have moved the understanding of planning towards a wider spectrum of city-making practices, beyond disciplinary and professional boundaries, and in which some forms of participation become the very practice of planning. This article builds upon those debates, proposing an understanding of 'participation as planning'. Building on Southern urban theory, and recognising the difference between a discussion about participation and one that looks at planning through participation, the article proposes to recognise that there is a range of experiences of participatory city-making taking place in urban contexts, some of which fall into one of the referred categories, while others have remained as a 'blind-spot' in planning debates. The article identifies and discusses a series of strategies that have emerged from Southern contexts, and that represent ways of dealing with planning limits: Collective forms of spatial production that respond to the inadequacy of planning instruments to engage with diverse processes of city-making situated beyond dominant practices; partnership-oriented practices that react to the neoliberalisation and financialisation of planning; and advocacy-oriented practices to contest abusive planning practices which violate human rights.
\end{abstract}

\section{Introduction}

Urban planning has been for decades under scrutiny due to the evident limitations of existing practices and instruments to address growing challenges of social and spatial injustices. Different approaches have emerged as a response to these issues, including those perspectives that have been gathered under the umbrella of 'collaborative planning' and have centred participation in planning practices. Promoting people's participation in city-making processes has become one of the key issues for most disciplines working on the built environment, becoming a term loaded with lots of imaginative potentials and political contestations. Participation in planning is seen as a fundamental tool to carry out urban interventions in more effective, sustainable, and democratic ways; it has become a mechanism to recognise people's voices, knowledge and practices in city-making processes, opening up questions of governance beyond the urban realm. Such collaborative approaches, however, appear insufficient when confronted with the magnitude of current planning challenges. Drawing on previous discussions about co-production, post-collaborative, agonistic and insurgent planning, this article proposes an understanding of 'participation' not as an instrument 
to implement urban plans, but as a form of planning practice itself.

These debates have been addressed in the past. The limitations of collaborative or communication planning, and of what has called state-initiated co-production (Watson, 2014) have been widely problematised by existing literature (Watson, 2002; Harrison, 2006, Brownill and Parker, 2010; Legacy, 2017; Thorpe, 2017). This critique is particularly relevant regarding the inability of such approaches to re-negotiate power imbalances in the planning processes and to provide responses to urban challenges in extremely unequal urban contexts. Notions such us insurgent planning (Miraftab, 2009), post-collaborative planning (Brownill and Parker, 2010) movement-initiated co-production (Watson, 2014), socio-spatial learning (Natarajan, 2017), participation as political (Legacy, 2017) and agonistic practices (Gunder, 2003; Mouat et al 2013; Thorpe, 2017; Yamamoto, 2017), are examples of approaches that see participation not only as a 'tool' for the implementation of planning, but as a form of planning itself. In this paper, we want to build upon such debates, exploring the diversity of strategies that people and movements are developing to respond to the limitations of planning disputing the meaning of it, which includes approaches that the referred literature has already captured. Some of the strategies we will discuss fit into these categories, while others may be slightly different: we look at various forms of participatory engagement that have already emerged as a response to planning limitations, proposing a shift of the discussion from 'participation in planning' to 'participation as planning, recognising the difference between a discussion about participation and one that looks at planning through participation, a notion we will elaborate throughout this paper. We hope this approach will help to recognise practices that are often left out by existing narratives about 'participation in planning'.

We refer to examples coming from the global South, suggesting that lessons learned from these cases can contribute to wider planning research and practice debates. The paper draws on critical perspectives emerged from Southern theory, understood not as a limited geographic location, but as an ethos of inquiry (Bhan et al, 2018). A reframed definition of the limits of planning from a Southern perspective, we suggest, calls for a reconfiguration of existing understandings of planning itself, reconsidering the role of participation in such definition. We have deliberatively decided not to focus on one or two examples, but to acknowledge a diversity of experiences and strategies taking place. We have prioritised to discuss a wide range of cases as a provocation to reframe the discussion of participation and planning, capturing different trajectories that participation strategies are taking, and contesting the notion of planning as a closed sphere of inquiry.

The strategies discussed are based on our own work engaging with a variety of practices; we seek to make sense of these experiences avoiding the imposition of theories and values on them, but rather discussing these practices and knowledges within the frames and languages they have been presented to us, recognising their importance to recalibrate the discussion about planning through people's experiences. Throughout this reflection, we hope to propose ways of reconfiguring participation not as a means to implement urban planning, but as a form of practicing and researching planning.

The article starts by positioning the debate of 'participation in planning', introducing some of the critiques that have emerged to 'collaborative' approaches, and the series of approaches to participation and planning that have arose as a result to those critiques and limitations. Recognising these limitations, the second section focuses on 'participation as planning'; building on Southern urban theory, we propose to bring into dialogue these different approaches, recognising a series of ongoing efforts of participatory city-making as actual forms of planning. We then identify a series of strategies that have emerged from Southern contexts. We propose that each of these strategies represents a way of dealing with planning limits: collective forms of spatial production that respond to the inadequacy of planning instruments to engage with diverse processes of city-making situated beyond dominant practices; partnership-oriented practices that react to the neoliberalisation and financialisation of planning; and advocacy-oriented practices to contest abusive planning practices which violate human rights. After presenting the cases, the article concludes by discussing the value of using 'participation as planning' as an approach that allows to problematise some of the 'blind-spots' generated by current planning theory and practice.

\section{Participation in planning}

In an article published in the first issue of Planning Theory in 2002, Vanesa Watson asks to what extent normative approaches to planning emerging in the West during the last decades have relevance in SubSahara Africa. In so doing, she identifies three main normative approaches to planning: communicative planning theory, led by authors such as Patsy Healey, John Forester and Judith Innes; the just city approach, developed mainly by Susan Fainstein; and approaches 
focused on issues of cultural differences and recognition of diversities, as those of Leonie Sandercock (Watson, 2002). These collaborative understandings of planning have emerged as responses to the growing challenges of governing urban development and to propose normative approaches that can stop the reproduction of urban inequalities and injustices. They emerged to address the unquestionable limitations of positivist, centralised and usually top-down existing planning tools, through approaches that "[give] priority to the process through which decisions are made and stresses the significance of undistorted speech, [allowing] the relation of group identities and the explicit recognition of difference [...] to define a desirable set of social relations" (Fainstein, 1999: 259-260).

These approaches have been widely spread among researchers and practitioners who have found in relational understandings of planning, tools to address the complex socio-spatial challenges that city-making brings about. Through participatory mechanisms, planning has attempted to recognise people's voices and practices in processes of city-making. Watson closes the same article, however, presenting a rather bitter conclusion, pointing out at how these normative views may enhance processes of depoliticization of planning and - particularly in cities of the global South - are not necessarily able to address the underlying structures behind inequalities:

With no new development paradigm on the horizon, postmodernists and cultural-turn scholars retain a faith in civil society and social movements to build democracy and local economic development. Their vision of society is one of a diversity of groups with different values, interacting via porous frontiers and blurred borders (Storper, 2001). This is a view not incompatible, Storper argues further, with the friendly, consumerist world of neo-liberalism, and one that is equally depoliticizing (Watson, 2002: 46).

Watson's claims conclude by suggesting that rather than a 'cultural-turn' and a blind support to 'the local', overlooking the importance of strong governments, urban challenges need today of a vision that "lends support to a form of planning that recognizes that 'the local' both shapes, and is shaped by, broader structural forces" and "lends support to a form of planning which acknowledges the material basis of identity struggles" (Ibid: 47). As Harrison says, "[a]lthough the trend [of collaborative planning] is away from the once dominant constructions of Western (Occidental) rationality, it remains a concern that the body of work known as 'planning theory' has developed almost entirely within the framework of Western intellectual traditions" (Harrison, 2006: 319).

The limits of participation in planning have been widely acknowledged. From the publication 50 years ago of $A$ Ladder of Citizen Participation (Arnstein, 1969) and its critical account of the distribution of power in participatory processes, to the publication of books with titles such as The Nightmare of Participation (Miessen, 2009) or Participation: the new tyranny? (Cooke and Kothari, 2001), many authors from different disciplines have called for a revision of a " [s] implistic understanding of 'communities' [that] see them as homogenous, static and harmonious units within which people share common interests and needs" (Cooke and Kothari, 2001: 6). The literature exploring participatory processes more generally has used the language of invited and claimed spaces of participation to unpack the different conditions within which participation has been practiced (Cornwall, 2002). As a result, participation in planning has often been criticised on the basis that it has led to the prioritisation of local actions, potentially leaving structural processes unchallenged (i.e. Flyvbjerg, 1996; Storper, 2001; Purcell, 2006). The 'communicative turn' of planning has been contested by several authors, indicating that "there is a tendency in some of the communicative literature to privilege communication at the expense of its wider social and economic contexts" (Huxley and Yiftachel, 2000: 333); and questioning the extent to which collaborative approaches have been able to challenge the universal claims of planning, as it "is still portrayed as an unproblematic global activity, adhering to similar logic of communicative rationality wherever it is found" (Huxley and Yiftachel, 2000: 336). Natarajan, on the other hand, has suggested to build upon collaborative notions adding an explicit focus on socio-spatial learning; as she points out:

Collaboration in planning theory has provided three focus areas: communicative processes; dealing with conflict; and relative power positions of actors. Socio-spatial learning offers a fourth area, which is particularly relevant to community engagement. (...) 'socio-spatial learning' rests on the premise that spatial planning knowledge is reworked or reframed upon community engagement (Natarajan, 2017:6).

Critiques have also pointed at the tendency of collaborative planning to focus on consensus building, hiding social complexities and leading to limited recognition of social diversity. As argued by Miraftab:

decades of professional planning practice that advocates inclusion through participation 
have shown that its conception within liberal ideals obscures, and at best is unable to address, complex layers of conflict, oppressive power, and imposition (...). Inclusive planning through citizen participation has, indeed, often served as an alibi for elitist, private-sector-driven decision, or as cheat compensation for state withdrawal from public and social services (Miraftab, 2018: 277).

Literature that has focused particularly on issues associated to participation in processes of planning and design in informal settlements in the global South have called for a critical engagement with the social identities being represented, raising questions around mis- as well as mal-recognition reproduced through participatory processes (Walker and Butcher, 2016; Rigon, 2017). Likewise, authors have interrogated how participation could end up benefiting more organised and mobilised urban communities, leaving most deprived, fragmented and marginalised groups behind (Lemanski, 2011). Frediani (2016) focuses on tensions related to the articulation between the social and the physical aspects of participatory design in informal settlement upgrading processes, highlighting the challenges to engage with heterogeneity within communities and their inner power asymmetries; issues of scale; and issues of time.

Critiques to 'participation in planning' have led to the development of a series of proposals that build beyond collaborative approaches. Part of this critique calls for re-thinking 'where' planning takes place, recognising the role of everyday practices as a site of production of regulations, frameworks and procedures that shape city-making. This literature has called for alternative planning thinking, critiquing consensus building approaches, and drawing on experiences of insurgency (Miraftab, 2009) and acknowledging conflict as a necessary aspect of collaborative and democratic planning (see Gualini, 2015). The notion of agonistic planning (Gunder, 2003; Mouat et al, 2013; Yamamoto, 2017) has gained centrality as a way to politicise the need of pluralism, diversity and inclusion in planning processes; in the same lines, notions such as 'productive tension' are approached as "a politics of friction, or points of contention that have arisen as differentially positioned actors articulate, grapple with, and fight over mismatches in visions and processes" (Kiefer and Ranganathan, 2018: 3). Then, conflict in planning is not seen as a synonymous of violent confrontation but "as a constitutive element of social relations and as a source of their strength and ability to innovate" (Gualini, 2015: 3). Likewise,
Miessen (2010) has referred to conflict "as one that is neither physical nor violent, but a friction that emerges on a content and production level, a conflict played out within the remit of the democratic arena" (Miessen, 2010: 101). Claims of the same nature are introduced by geographers such as Erik Swyngedouw in his 2011 essay, Designing the Post-Political City and the Insurgent Polis, referring to the 'post-political consensus' city, where neither democracy nor politics are possible, and calling for "thinking through the city as a space for accommodating difference and disorder [which] hinges critically on creating egalibertarian public space" (2011: 52). A relational understanding of planning that doesn't give space to conflict, one could argue, implies that usually some privileged positions will be dominant, denying the possibility of other voices to emerge.

Identifying the emergence of this 'post-collaborative' era, Brownill and Parker (2010) have called for:

more nuanced analyses of the conflicting rationalities underlying planning practice and the dynamics and contradictions often found at the micro-level are emerging. This may be termed a post-collaborative phase, which emphasizes the difficulties and challenges of participation from different perspectives and highlights the range of contexts and conditions that are producing and shaping participatory episodes (Brownill and Parker, 2010: 276).

While not explicitly delving into more detail on the implications of this towards an expansion of the understanding of planning practice, Brownill and Parker (2010) have emphasised the need for reflexivity in participatory processes, unpacking the relations of power embedded in them.

In similar lines, Legacy (2017) describes the crisis of participatory planning generated by the consensus and outcome driven processes serving the "narrow economic growth logic over more challenging questions relating to the equitable distribution and access to critical social and public infrastructure" (2017: 428). Legacy calls for more agonistic practices to be recognised as part of planning processes and as a mechanism to politicise formal planning processes. By developing the concept of 'participation as political', Legacy outlines that:

Critics argue that consensus-based participatory processes evade the political in planning which prevents citizens from challenging public 
discourse and orthodoxy about the way the urban is constituted and recreated, but also the very basis upon which participation is often constituted and the planning it produces. Instead, those passionate and active citizens will seek out alternative, informal spaces outside formal government processes to politicise participation and offer alternative solutions to city challenges. (Legacy, 2017: 430).

Legacy goes a step further to Brownill and Parker (2010) by arguing for the need to approach 'informal spaces outside formal government processes' as part of planning processes, however that is still conceptualised in relation to its influence on formal planning processes. In a sense, agonism is captured in terms of deepening the democratic practices within collaborative planning processes.

Thorpe (2017) contributes to this debate, by arguing that the existing historical accounts of the relationship between participation and planning often start from the 1960s and ignore citizen-led activities that have taken place outside government-led spaces: "planning is more than what planners do, and participation is more than what planers invite" (2017: 577). Furthermore, she argues:

Rather than focusing on those processes to which citizens are invited to participate, inclusion requires attention to the full range of activities intended to shape the city, from small-scale contributions by citizens and community groups to much larger interventions by corporate developers (Thorpe, 2017: 577).

In this article, we would like to build on Thorpe's concern, by arguing that conceiving 'participation as planning' can help to recognise the practices often left out by existing narratives about 'participation in planning.

\section{Participation as Planning}

The idea of participation as planning hopes to bring into dialogue the different approaches that have positioned planning within the field of participation, avoiding definitions of participation as a tool for implementing planning as a closed field. What approaches such as insurgent or post-collaborative planning, movement-initiated co-production, agonistic practices or participation as political have in common, is the understanding of urban planning as a wide spectrum of city-making practices, beyond disciplinary and professional boundaries, and in which forms of participation become the very practice of planning. We refer to these practices as 'participation as planning', recognising that there is a range of experiences of participatory city-making taking place in urban contexts, some of which fall into one of the categories discussed above, while others have remained as a 'blind-spot' in planning debates. Then, our understanding of planning draws on Thorpe's definition, who sees planning as:

not a singular, specific thing: it is a plurality of practices constructed and enacted by people in social and material contexts. When the subjects of planning advocate for changes to the form of the city, when they directly intervene in the built environment in ways that challenge, confirm or reinterpret official plans, and when they report, ignore or actively conceal violations to planning rules and policies, they participate directly and often materially in the practice of planning (Thorpe, 2017: 577).

Assuming this expanded understanding of planning, it becomes crucial to explore in more detail how it relates and overlaps with other forms of city-making, beyond those that interact directly with formal planning systems. These notions and exploration go beyond the scope of this paper. However, in the context of this reflection, we understand city-making practices as the range of activities that take place in the production of urban space, recognising everyday practices and other forms of social production of space beyond dominant and official planning practices. This approach relays on Lefebvre's idea of social production of space, which sought "to expose the actual production of space bringing the various kinds of space and the modalities of their genesis together within a single theory" (Lefebvre, 1991:16). Then, 'participation as planning' is about recognising a series of ongoing efforts of citymaking as actual forms of planning. In current debates, participation in planning has often instrumentalised the role of participation as a tool to address or implement particular pre-defined visions of planning. As discussed, this approach has failed to recognise that there are planning concepts, discourses, procedures, practices and imaginaries being produced through bottom up, civic-led processes of spatial production.

In order to recognise those alternative practices, a Southern urban theory perspective helps to problematise this 'blind-spot'. The body of literature about urban issues concerning global South cities covers a wide range that goes from Milton Santos' 
books in the 1970s, till the recent publication of The Routledge Companion to Planning in the Global South in 2018, including authors from different disciplines, intellectual trajectories and geographies, such as Ananya Roy, Susan Parnell, Gautam Bhan, Jennifer Robinson, Caren Levy, Vanesa Watson, Aihwa Ong, to name just but a few. Inherently, what these authors bring about to the discussion is not just a set of geographies, but an approach to urban planning that challenges existing geographies of knowledge production and circulation. As Harrison points out, their efforts focus on developing 'other thinking', looking to offer an alternative to exiting intellectual traditions, as part of a post-colonial project that can give space to subaltern knowledges that have emerged in geographies with different trajectories of modernisation (Harrison, 2006). Then, a Southern perspective becomes more than a set of locations: it is an ethos of enquiry in which 'place matters', that can be seen "as a periphery, $[\ldots]$ a relational geography. It is not just a collection of previously underdeveloped countries or the boundaries of the post-colonial world but a dynamic and changing set of locations" (Bhan et al, 2018: 5).

A Southern approach helps to recognise the referred blind-spots; their invisibility contributes to the reproduction of asymmetries of power in planning research and practice debates, where academia theorises 'about' places and not 'through' them, as pointed out by Gautham Bhan (2018). The South, then, becomes "as much a project as a place, a relational geography that insists on calling out hegemonies of knowledge and dominant forms of practice no matter where they emerge" (Bahn, 2019: 4). A Southern urban theory perspective pushes as to understand participation as a practice of producing the city, therefore, situating and locating planning through it. 'Participation as planning' is most of all an 'ethos of enquiry' to interrogate planning through people's experiences when trying to produce more equitable cities.

We propose that looking at these cases can contribute to the conversation by recognising a series of aspects. First, in order to recognise 'participation as planning', these experiences invite us to engage with the history and trajectories of oppression of the places, approaching participation as a means to encourage a 'historicized consciousness' and promote "historical memory of present experiences" (Miraftab, 2009: 46). Second, they call for an understanding of planning as a public learning process, recognising and supporting grassroots efforts of city-making through everyday practices, and also their participation in 'invited spaces' created by dominant urban planning stakeholders. This implies recognising and supporting confrontations generated through grassroots' oppositional practices as they create spaces of negotiation in their own terms of engagement. Third, they challenge a problemsolving perspective, understanding that planning and design should open up possibilities, scenarios and opportunities for change, rather than look for agreements on common denominators. This, in Nabeel Hamdi's words, implies to understand "design as the subject rather than object of community participation, not the result of the process, but the means to it" (Hamdi, 1995: 86). And finally, they allow to propose alternative imaginaries of the future, grounded on solidarities based on shared histories of oppression, which enable the construction of more socially and spatially just urban imaginaries. The 'ethos of enquiry' brought about by Southern urban theory calls us to theorise through places rather about them; likewise, we have proposed in this article to discuss planning through experiences of city-making, interrogating participation processes as modes of production that are centred in people's engagement towards more equitable cities.

\section{Strategies from the South}

In what follows we present cases of participatory engagement that we consider that have emerged as a response to the limitations of dominant planning. We identify three kind of strategies that have emerged from Southern contexts responding to different planning limits. These analytical distinction helps to distinguish how dominant planning arrangements are contested in different ways; however, it is important to point out that in practice many of the organisations we discuss here have used more than one of these strategies simultaneously. Through the problematisation of these strategies, we discuss the extent to which they challenge or/and reproduce planning tensions. Lessons learned from these cases aim to shed light beyond the borders of the South, reconfiguring participation not as a way to implement urban planning, but as a new form of planning practice.

Table 1 summarises the experiences discussed below. The variety of cases presented might lose the capacity to explore each of them in depth, but provides an opportunity to set new meanings and explore some of the multiple narratives of city-making that are taking place. The table also shows the kind of engagements that we have had with them, from which the language, knowledge, concepts and ideas presented have emerged.

Firstly, there has been a series of strategies that have emerged as a response to the inadequacy of planning 
Table 1. Participation as planning, strategies from the South: Cases and methods of engagement.

\begin{tabular}{|c|c|}
\hline Case & Engagement \\
\hline $\begin{array}{l}\text { South African Slum/Shack } \\
\text { Dwellers International (SDI) } \\
\text { Alliance }\end{array}$ & $\begin{array}{l}\text { Knowledge shared through action learning engagements from } 2011 \text { to } 2017 \text { during the MSc module } \\
\text { on Community Development at the University of Cape Town and complemented by desk research. }\end{array}$ \\
\hline $\begin{array}{l}\text { Federation of Urban and } \\
\text { Rural Poor - Sierra Leone } \\
\text { (FEDURP-SL) }\end{array}$ & $\begin{array}{l}\text { Qualitative research undertaken on the role of Community Action Area Planning in the expansion } \\
\text { of participatory capabilities in Freetown in 2018. Collaborative research with SLURC as part of the } \\
\text { ongoing research project, Knowledge in Action for Urban Equality (KNOW). }\end{array}$ \\
\hline $\begin{array}{l}\text { Habitat International } \\
\text { Coalition (HIC) - Social } \\
\text { Production of Habitat }\end{array}$ & $\begin{array}{l}\text { Experience acquired through various learning and capacity building activities conducted by HIC as } \\
\text { well as semi-structured interviews and desk research conducted by MSc student Blanca Larraín for her } \\
\text { dissertation project. }\end{array}$ \\
\hline $\begin{array}{l}\text { Asian Coalition for Housing } \\
\text { Rights (ACHR) - ACCA } \\
\text { Programme }\end{array}$ & $\begin{array}{l}\text { Action learning engagement facilitated through field-trips conducted as part of the MSc Building and } \\
\text { Urban Design in Development, in Bangkok (2012) and Myanmar (2017). Collaborative research with } \\
\text { ACHR as part of the ongoing research project, Knowledge in Action for Urban Equality (KNOW). }\end{array}$ \\
\hline $\begin{array}{l}\text { Orangi Pilot Project- } \\
\text { Research and Training } \\
\text { Institute (OPP-RTI) }\end{array}$ & $\begin{array}{l}\text { Knowledge shared by Arif Hasan during interview in } 2013 \text { as part of the research project "Thinking } \\
\text { across boundaries: Planning Dilemmas in the Urban Global South"; knowledge shared by Arif Hasan } \\
\text { during the } 2016 \text { International Exchange Event in London organised by DPU with the Sierra Leone } \\
\text { Urban Research Centre; and complemented by desk research. }\end{array}$ \\
\hline $\begin{array}{l}\text { Delegated Management } \\
\text { Model in Kisumu }\end{array}$ & $\begin{array}{l}\text { Action learning engagement facilitated through field-trips conducted as part of the MSc in Social } \\
\text { Development Practice in 2013,2014 and 2015. Research methods included a series of participatory } \\
\text { action research activities, such as participatory photography, mapping, focus group discussions and } \\
\text { semi-structured interviews. }\end{array}$ \\
\hline FUCVAM - Uruguay & $\begin{array}{l}\text { Knowledge shared by FUCVAM representatives and partners at Habitat International Coalition } \\
\text { general assemblies in 2015, } 2016 \text { and } 2017 \text { and complemented by desk research. }\end{array}$ \\
\hline $\begin{array}{l}\text { Occupations in vacant } \\
\text { buildings in São Paulo }\end{array}$ & $\begin{array}{l}\text { Research conducted as part of the Insurgent Regeneration research project from 2015-2017, through } \\
\text { semi-structure interviews and mapping research activities. }\end{array}$ \\
\hline $\begin{array}{l}\text { HLRN, Right to the City } \\
\text { Charter in Greater Beirut }\end{array}$ & $\begin{array}{l}\text { Knowledge shared by HLRN representatives at the Global Platform for the Right to the City event in } \\
\text { Nairobi (2018) and complemented by desk research. }\end{array}$ \\
\hline $\begin{array}{l}\text { Bimkom - Planners for } \\
\text { Planning Rights, Jerusalem }\end{array}$ & $\begin{array}{l}\text { Knowledge shared by Bimkom founder Haim Yacobi, as well as other Bimkom team members, as } \\
\text { part of the DPU summerLab workshop "Jerusalem } \backslash \text { Al Quds: [Inter]Sections of Urban Conflicts", in } \\
\text { September } 2017 \text {. }\end{array}$ \\
\hline $\begin{array}{l}\text { Abahlali baseMjondolo, } \\
\text { Durban }\end{array}$ & $\begin{array}{l}\text { Knowledge shared by Abahlali baseMjondolo representatives at the Global Platform for the Right to } \\
\text { the City event in Nairobi in } 2018 \text { and complemented by desk research. }\end{array}$ \\
\hline $\begin{array}{l}\text { Justice \& Empowerment } \\
\text { Initiatives - Lagos }\end{array}$ & $\begin{array}{l}\text { Research conducted for project on role of participatory well-being assessment in supporting the } \\
\text { capacity of informal settlement dwellers to resist evictions in Lagos, Nigeria. Research methods } \\
\text { included participatory video as well as focus group discussions and semi-structured interviews. }\end{array}$ \\
\hline
\end{tabular}

instruments to engage with diverse processes of citymaking situated beyond dominant practices. This inadequacy is particularly significant in geographies where subaltern knowledges are manifested in practices that are not recognised by planning frameworks and the intellectual traditions that are at their base. As Santos (1979) pointed out decades ago, urban 'lower circuits' present 'inherent characteristics' usually invisible to the available tools of professional planning. The current discussion on cities in the global South cities have recognised this phenomenon in several ways, particularly when referring to informal economic, social and spatial arrangements; Roy (2009), for example, has called for the understanding of 'idioms of urbanisation' in Indian cities, as planning regimes that are particular to the country's political economy. A general call for challenging the notion of illegality of informal settlements, as well as dismantling dichotomies between formal and informal, are expressions of the inadequacy of planning frameworks to operate in cities in which sometimes the majority of citizens can be potentially labelled as 'illegal'.

We can find a set of strategies that challenge this inadequacy of planning instruments, which we have called collective forms of spatial production. While being embedded in very different contexts, these are all grassroots-led processes of social mobilisation, production and management of space in the city. One of the most significant examples of this type of experience has been the work of various Federations of the urban spread mainly in the Asian and African continent 
and networked through Slum/Shack Dwellers International (SDI). Their work, which has been widely documented, has involved self-enumeration processes, recognising that the urban poor can enhance their power to influence urban decision-making by generating and owning the knowledge about their living conditions. In Cape Town (South Africa) for example, enumeration exercises facilitated by the South African SDI Alliance have led to experiences of reblocking of informal settlements, where communities re-plan their settlements in-situ, enhancing access to services as well as improve living conditions (see Kiefer and Ranganathan, 2018). In Freetown (Sierra Leone), Federation members have organised under the Federation of Urban and Rural Poor - Sierra Leone (FEDURP-SL) and worked with the Sierra Leone Urban Research Centre (SLURC) and Architecture Sans Frontières-UK to develop Community Action Area Plans, which have supported existing processes of bottom-up and civic-led informal processes of slum upgrading, as well as coordinated interventions done in partnership with NGOs and government authorities (see Macarthy et al, 2019).

In Latin America, Habitat International Coalition (HIC) has been supporting exchanges and systematisation of similar community-led processes of city making, by recognising them as 'social production of habitat' (Ortiz, 2007; Zárate, 2018). According to HIC, social production of habitat is a peoplecentred and people-driven process of designing, planning, building, maintaining and inhabiting spaces, addressing historical social and spatial challenges. These practices are defined as complex and dynamic processes, built through social movements and interactions among urban dwellers and driven towards social transformation (Jakob, 2003; Ortiz and Zárate, 2004; Romero, 2003). Therefore, as summarised by Larrain, the process of social production of habitat "accounts for an improvement in material terms, but more important, it can represent a way of using and appropriating the city. A mean for advancing the emancipation of socially excluded and segregated groups" (Larraín, 2019: 1).

In South East Asia, similar processes have been enabled and supported by the Asian Coalition for Housing Rights (ACHR), a network of grassroots groups, activists, NGOs and professionals that has operated in the region for more than 30 years, supporting community-driven processes of slum-upgrading based on collective saving groups, mapping, and innovative

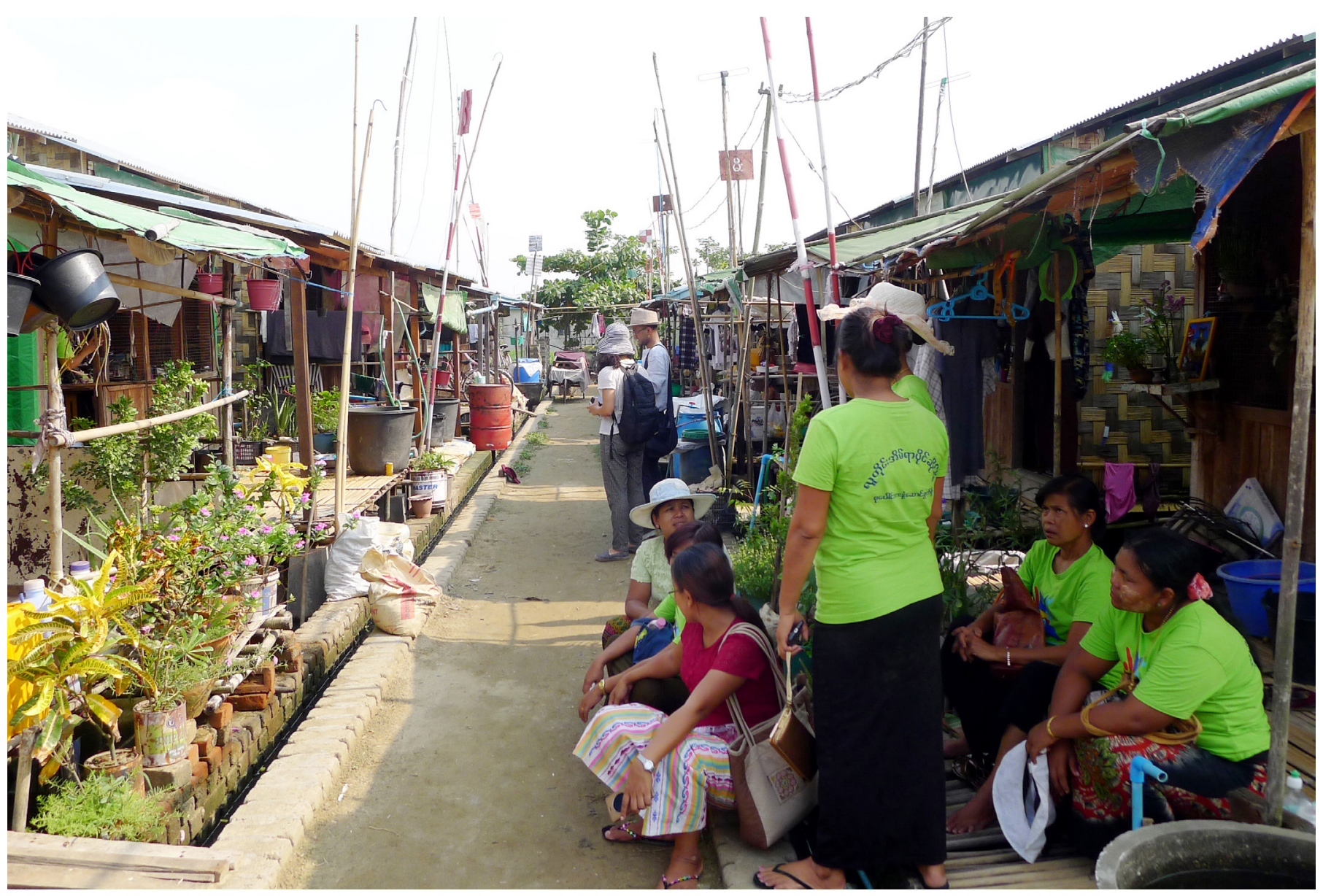

Figure 1. Members of Women for the World, part of the ACHR network, in one of the settlements upgraded by the community using collective savings in Yangon, Myanmar. Author: Camila Cociña 
land tenure and financial models. Collaborating with other regional groups such as the Community Architects Network (CAN), ACHR has worked during the last decade with hundreds of communities across nineteen countries of South East Asia, influencing policies and development partnerships for the implementation of the Asian Coalition for Community Action programme (ACCA), a peoplecentred citywide upgrading programme that sought to work in 150 Asian cities (see Boonyabancha and Kerr, 2019; Boano and Astolfo, 2016).

Underpinning these various experiences is a fundamental recognition that dominant planning practices have been unable to respond to the needs and aspirations of the urban poor. These initiatives demonstrate the agency of organised grassroots groups in leading processes of city-making in their own terms, and in challenging the spaces and forms in which urban planning take place beyond official programmes. While these practices set precedents for more inclusive forms of spatial production, they have also faced substantial difficulties in challenging existing inequalities and power imbalances within and among 'communities'. While the concept of 'community' is often used by such actors to recognise the voices and capacities of marginalised groups, it has been also argued that it becomes an obstacle to have a more critical reflection and analysis of the potential miss-recognitions within groups. Existing studies (see Walker and Butcher, 2016; Rigon, 2017) have called for more investigation on the extent to which such practices can have a more equitable distribution of benefits and hazards, as women seem to bare a lot of the hardships associated to social mobilisation, and tenants often not being able to enjoy as much as structure owners the benefits from collective action in informal settlements. Therefore, a key tension among these set of practices is how not to 'leave behind' the less organised, marginalised and vulnerable groups that face more obstacles to engage in such processes. Likewise, how to deal with city-wide processes and needs beyond organised neighbourhoods. Therefore, instead of joining top-down, predefined and invited spaces of participation, these experiences call for public, market and civil society actors to support and enhance the ability of grassroots collectives to be more inclusive and sustain ongoing initiatives.

A second limitation of planning is manifested by its neoliberalisation and over-financialisation, that affect not only the economic logic behind city production and investment, but the whole nature of city and resources governance. These dynamics are generating processes of exclusion that affect disadvantage population all over the world, but have a particularly dramatic version in countries with already weak institutions and states, which face even more precarious conditions to conduct their duties. The extensive work of David Harvey (1982; 2008) discusses the role of urbanisation processes in capital circulation, and how the neoliberalisation of the processes of value creation through urbanisation has fostered concentration patterns of surplus distribution. Then, one of the main questions for planning becomes "who commands the necessary connection between urbanisation and surplus production and use" (Harvey, 2008: 40), which has become a central issue in many of the contemporary debates about urbanisation, segregation, gentrification, land value, and so on. As Madanipour reflects, "[c]ommodification of space has led to different patterns of access to space and hence a differential spatial organization and townscape" (2007: 163), in which exclusion becomes an institutionalised mechanism to control access to the city's resources.

As a response to these dynamics, there has been various experiences of 'participation as planning' in the global South that take place through partnershipbased approaches established by organisations of the urban poor with state and/or private companies. Sometimes relying on existing planning tools, these approaches tend to recognise and enhance the role of such organisations in the management and delivery of urban services. Sometimes referred as 'pro-poor private public partnerships', these experiences have led to various models for participatory governance of urban service, in a context of a growing privatisation of urban development more generally. A well-known and meaningful initiative in this context has been led by the NGO Orangi Pilot Project-Research and Training Institute (OPP-RTI), which works in the town of Orangi in Karachi (Pakistan), and other Pakistani cities. The OPP-RTI's low-cost sanitation programme is based on a partnership model in which sewerage systems inside the houses and neighbourhood are developed by communities themselves and are linked to 'external' sewer system developed by the local government. The success of a big number of the OPP-RTI projects has "demonstrated that communities can finance, manage and build internal sewerage development provided that they are organized and supported with technical support and managerial guidance" (Hasan, 2006:451). The lessons learned from this initiative have informed many other processes (see Allen et al, 2013), such as the implementation of 'delegation management model' in informal settlements in Kisumu (Kenya) to deliver water. The water and sanitation parastatal company KIWASCO agreed to supply water to neighbourhood 
planning associations from informal settlements, who then managed the water delivery to water kiosks and households. The system led to increased access to water while also strengthening of community representative structures of residents from informal settlements (see Frediani et al, 2016; 2014a; 2014b). Another example of similar type of partnership have taken place through more institutionalised processes of collective forms of housing production, such as the cooperative experiences in Latin America. With a slightly different nuance, FUCVAM (Uruguay) is often mentioned as one of the most meaningful experience in this field, due to its scale and strong community ownership; FUCVAM, the Uruguayan Federation of Housing Cooperatives for Mutual Help, is the oldest and biggest movement in the country; it was formed in 1970 by Uruguayan workers and is constituted nowadays for more than 500 federated cooperatives. They operate both contesting official proposals from the government, as well as finding ways of collaboration with different actors through subsidies, credits, and technical assistance (see González, 2013).

Across these various experiences of partnerships is the acknowledgement that privatisation of service delivery and the increasing of collusions between public and private actors have led to the production of more expensive and exclusionary cities. As a response, these experiences call for civic entities to broacher more empowering partnerships, sometimes taking place in the margins of planning systems. Nevertheless, these processes have been exposed to the constant threat of reproducing the similar exclusionary market trends, reframing civic initiatives into the logic of enterprise development and transforming them into a purely service delivery agent. The implication of this threat is the uneven and unfair distribution of benefits between partnering actors, and where the logic of 'productivity', 'efficiency' and 'competitiveness' end up creating the conditions for formal market forces to enter informal areas without the necessary protections in place to safeguard the most vulnerable. Such threat has been captured by studies that have pointed to the overlaps between the language and practice of participation with principles and processes of market enablement and the rollback of the state from its welfare responsibilities (see Burgess et al, 1997). Therefore, the main lessons from these partnerships relate to the fundamental need for empowering regulatory frameworks, which produce incentives and regulations that supports civic entities, enabling them to play a meaningful role in redistributing benefits while also participating in wider processes of decision-making.

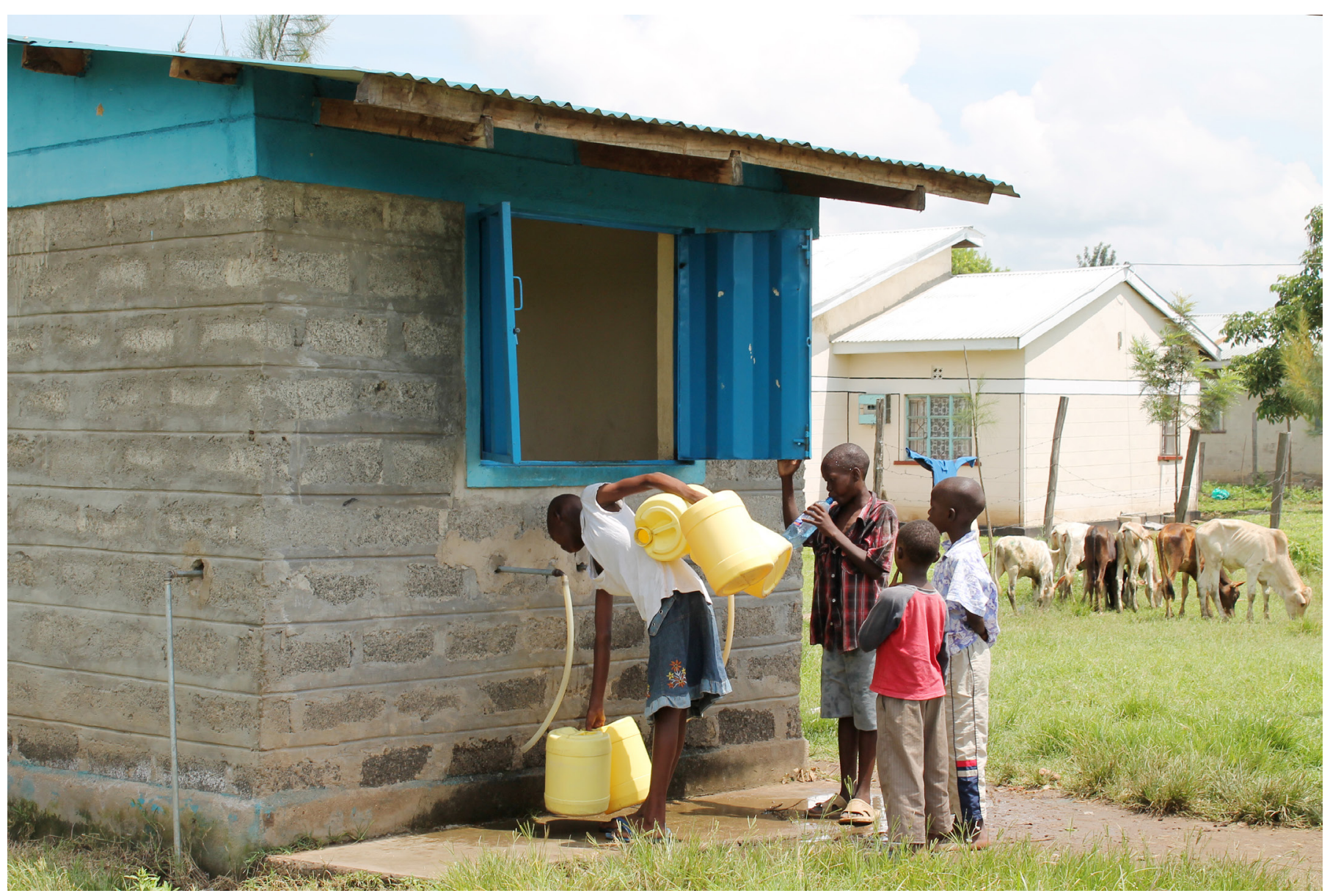

Figure 2. Water Kiosks in Kisumu, Kenya. Author: Fernando Martínez 
Finally, we identify that a third manifestation of current planning limits is the existence of abusive planning practices which violate human rights, specially where there are few capacities for the enforcement of rights-based frameworks. Planning and policy tools can act as a form of social control that can be manifested through either emancipatory reforms or oppressive control (Yiftachel, 1998). In this regard, planners and scholars have acknowledged how in certain context planning systems and the management of the city have been used as tools to deny rights to portions of the society, particularly more vulnerable citizens (Yiftachel and Yacobi, 2002; Yacobi, 2012). As a response to these dynamics, the third form of 'participation as planning' that we recognise, has emerged as a response to the growing violations of human rights taking place in cities of the global South, where marginalised groups have found mechanisms to use legal systems to recognise their role in planning and claiming for the right to the city. This rights-based approach has involved the use of legal systems and constitutional rights to condemn violations of rights in the city, relying on channels of governance that might be outside the planning system to open up opportunities and push for legislations and initiatives that can improve the quality of life of the urban poor. These experiences have been particularly relevant in Latin American cities, especially in Brazil, where the statute of the city' embedded in the Brazilian constitutions have created legal means to recognise the social function property and democratic forms of urban governance. An example of how this process has created the conditions for more insurgent forms of spatial production is the occupations of vacant buildings by housing social movements in the innercity area of São Paulo. Social movements have been able to legitimate occupations of vacant or underutilised buildings by arguing that they have not been exerting their social function. By entering the building and collectively refurbishing them to meet the housing need of marginalised groups and homeless populations, they have been able to demonstrate that they are bringing the building back to legality, and to raise the awareness of the need to produce 'social interest housing' in welllocated areas (see Frediani et al, 2019; De Carli and Frediani, 2016).

Meanwhile in the Middle East there has been also a growing amount of initiatives bringing together human rights, participation and planning. The recent efforts of producing the Right to the City Charter of Greater Beirut (Lebanon) is a good example of that.
This experience draws from other international efforts by urban social movements to produce city-charters that can influence planning, bringing together civic and government stakeholders from Beirut to produce a document that recognises "the concept of 'social function' of land, housing and related infrastructure and public goods and services, as well as the concept of the social production of habitat" (HLRN and Amel, 2018: 3). In Israel/Palestine, another example is the work of the NGO "Bimkom - Planners for Planning Rights", which since 1999 has focused specifically in preventing planning to violate human rights, assisting local communities in the effective exercise of their rights in issues related to housing, urban plans and infrastructure. Bimkom focuses particularly on the population that is more vulnerable to rights violations such as Palestinian communities in East Jerusalem and the West Bank (see Yacobi, 2007; Yacobi and Cociña, 2018).

In the African continent, there is also a growing recognition of legal avenues as a space to claim for more equitable forms of city-making. The urban social movement Abahlali baseMjondolo, which originated in Durban (South Africa), has used direct action as well as constitutional courts to stop evictions and advocate for more equitable access to adequate housing. The movement's activities have also focused on the democratisation of governance in informal settlements and improvements on the delivery of social services for the urban poor (see Huchzermeyer, 2014). In Lagos (Nigeria), Justice \& Empowerment Initiatives (JEI) have worked with the Nigerian Slum/Informal Settlement Federation through a community paralegal approach, which has been able to unlock various mechanisms to resolve disputes within communities while also winning court rulings condemning violations of human rights caused by forced evictions (see Frediani et al, 2018).

These initiatives highlight that dominant planning actors and actions have not been able to protect vulnerable groups against violations of their human rights, and more importantly that planning has become an instrument of such violations. No form of 'participation in planning' could possibly deal with the extent of this challenge, and therefore different groups have found ways to exercise planning through participation, using legal systems as an entry point. Increased financialisation of land and property markets have enabled the interests of global actors to be often prioritised over local needs and aspirations associated to social and environmental justice. As a result of this increased globalisation of real estate 
development, the urban poor have been experiencing systematic loss of entitlements and rights, deepening urban inequalities. The turn towards legal systems has emerged as a significant strategy to respond to these processes and the loss of a more socially justice-oriented agenda in dominant planning practice. While creating avenues for planning to be held to account to legally binding processes, these initiatives have also met the challenge of bias, fragile and uneven judicial systems. The limits of this rightbased approach have been captured by approaches of groups that have opted for paths that move away from 'openly aggressive and critical' campaigns, exploring collaborations that work closer to the state (Mitlin and Patel, 2005). This is particularly the case in the Asian context, where a pragmatic approach of what has been called 'politics of patience' has been central in the action of grassroots groups, pointing "to a logic of patience, of cumulative victories and of long term asset-building" (Appadurai, 2001: 30). Furthermore, there is still a lot to advance in the recognition and application of collective rights and the 'commons', as well as the various instances of judicial practices conditioned by everyday forms of use and production of the city.

\section{Final reflections}

Through this paper we have presented a series of cases to discuss the idea of 'participation as planning. We propose that the concept of participation, understood as a mode of planning, allows us to reflect and capture lessons learned from ongoing civicled experiences of city-making. We have discussed how collaborative approaches and experiences of participation in planning tend to see participatory processes as tools for implementing planning as a closed field; we hope that looking at experiences of participation as planning can bring into dialogue a wider spectrum of city-making practices, beyond professional boundaries, and in which forms of participation become the very practice of planning. As exposed by the debates presented in this paper, collaborative approaches to planning seem to be unable to deal with underlying power imbalances, as well as with the existing limits of planning, which we have summarised in three aspects: the inadequacy of dominant practices to engage with diverse processes, neoliberalisation, and the existence of practices that violate human rights. This proposal emerges as a way to make sense of experiences, practices

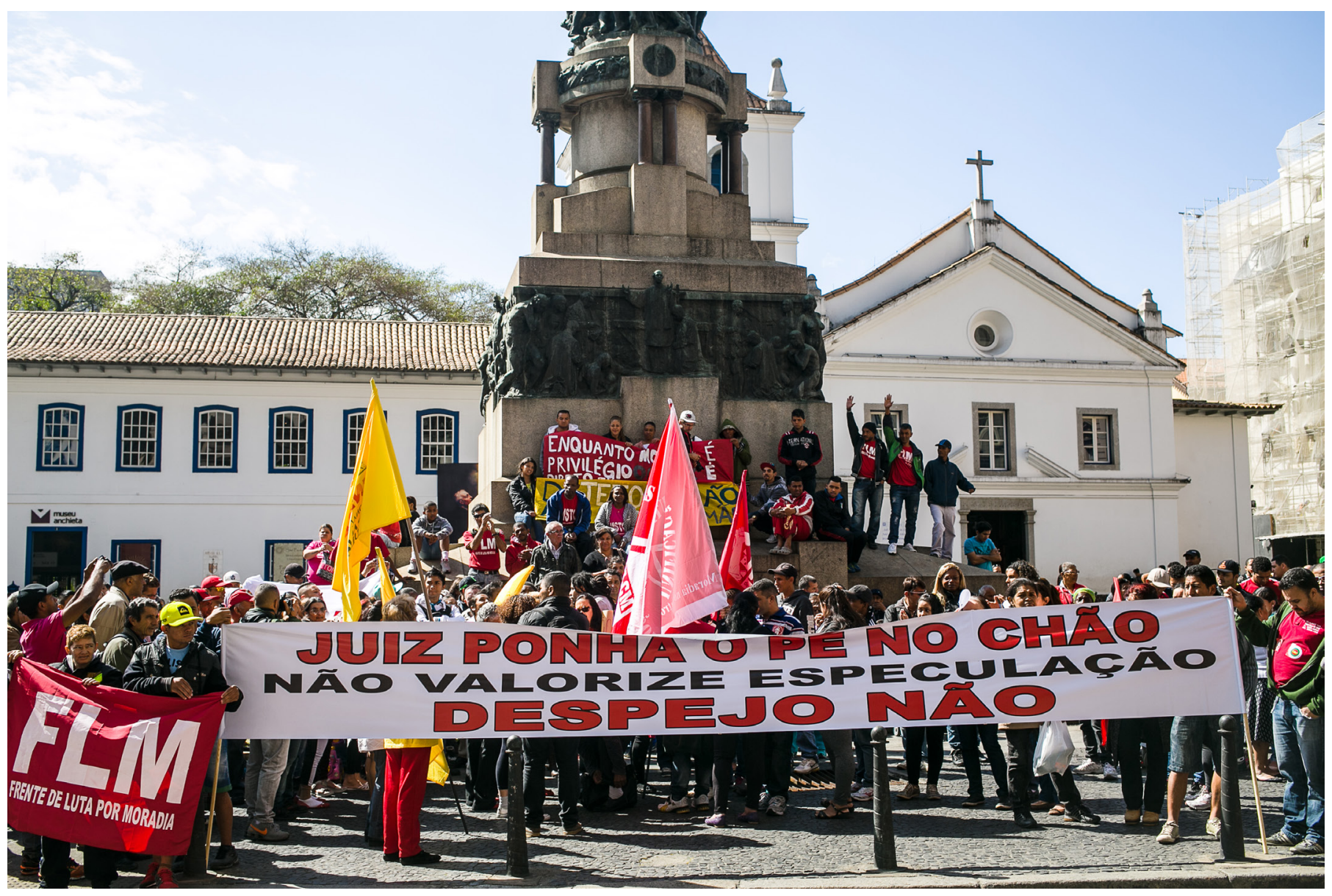

Figure 3. Demonstrations in São Paulo, Brazil, against evictions from occupied buildings in the city centre: 'Judge, put your foot down, do not encourage speculation. No evictions'. Author: Gabriel Boeiras 
and reflections we have encountered, and hopes to contribute to recognise the ways in which grassroots organisations have responded to the limitations of current planning practices.

In this paper we have attempted to shed light on some blind-spots, recognising participation as a form of spatial production that encompasses a spectrum of city-making processes, from small scale experiences of everyday practices, to large official city-wide initiatives; from forms of insurgent activism, to models of partnership, co-production and collaboration. Understanding that participation manifests in a wide repertoire of planning forms allows to avoid dichotomies between formal and informal, and approach city-making processes giving space to hidden, marginal or mis-recognised forms of planning. We have highlighted three kinds of strategies that we think give account of how experiences have emerged as a response to the current limits of planning; we are aware that there may be many other blind-spots in planning practices that will be important to explore in the future.

The paper has organised the cases in three kinds of strategies, but this analytical distinction shouldn't prevent us to understand them as interconnected approaches; in reality, many of the organisations we have discussed have used these strategies in simultaneous or complementary ways over time. The cases discussed in this paper are the result of a complex mash of informal and formal regulations, present in everyday forms of production, use and appropriation of space in cities. Then, these forms of city-making are sometimes collective and other times more individual practices. We don't want to romanticise them, and it is important to recognise that these forms of planning and participation are not always inclusive, fair or distributive. Rather, this approach to 'participation as planning' is an invitation to recognise these practices, interrogate and support them by addressing them as actual forms of planning.

Even if the examples discussed here are located in geographies of the global South, we suggest that they represent responses to the limits of planning in a variety of contexts, including cities of the North, and that the reflections emerged from them can bring useful lessons to the debates about participation and post-collaborative planning more widely. In this regard, we can find in the margins and peripheries, through people's experience of planning, potentials to provide clearer understanding of planning challenges more generally; or, as bell hooks points out, there is the potential of "choosing the margin as a space of radical openness" (hooks, 1991: 145). Reflecting through experiences taking place on the margins or peripheries doesn't mean to remain irrelevant for other geographies, but to open up spaces for reflection that are usually hidden for dominant planning discourses; peripheries, as Bhan reflects, "move across scale, space and time: the peripheries of the world economic and political system both historically and today; peripheries within cities themselves; peripheries of geographies of alternative knowledge" (Bahn, 2018: 5). This reflection is an invitation to recognise practices of planning through participation, opening up the possibility of engaging critically with the relationship between planning theory and practice. This paper has focused on recognising knowledges raising from a variety of practices, which we believe are central to interrogate planning theory and practice through the lens of social, spatial and environmental justice.

\section{Acknowledgements}

The authors would like to thank the extremely useful and productive comments provided by the anonymous reviewers, as well as the dedicated work and insightful suggestions made by the editor of this special issue, Lucy Natarajan. This paper was written with the support of the research project "Knowledge in Action for Urban Equality" (KNOW), funded by ESRC under the Global Challenges Research Fund (GCRF), project number: ES/P011225/1

\section{Bibliography}

Allen, A., Levy, C., Lipietz, B., and Marx, C. (2013). Thinking across boundaries - Planning dilemmas in the Urban Global South [Digital scholarly resource]. Retrieved from: https://www.ucl.ac.uk/bartlett/ development/about-us/dpu60/thinking-acrossboundaries

Appadurai, A. (2001). Deep democracy: urban governmentality and the horizon of politics, Environment \& Urbanization, 13(2), 23-44.

Arnstein, S. (1969). A Ladder of Citizen Participation, Journal of the American Institute of Planners, (35)4, 216-224, DOI: 10.1080/01944366908977225

Bhan, G., Srinivas, S. and Watson, V. (2018). The Routledge Companion to Planning in the Global South. Abingdon and New York: Routledge.

Bhan, G. (2019). Notes on a Southern urban practice, Environment \& Urbanization, 1-16.

Boano, C. and Astolfo, G. (eds.) (2016). Bangkok. On Transformation and Urbanism. London: The Bartlett Development Planning Unit. 
Boonyabancha, S. and Kerr, T. (2019). Lessons from CODI on co-production, Environment \& Urbanization, 30(2): 444-460.

Brownill, S. and Parker, G. (2010). Why Bother with Good Works? The Relevance of Public Participation(s) in Planning in a Post-collaborative Era, Planning Practice \& Research, 25(3), 275-282.

Burgess, R., Carmona, M. and Kolstee, T. (1997). Contemporary Policies for Enablement and Participation: A Critical Review. In Rod Burgess, Marisa Carmona and Theo Kolstee (Eds.) The Challenge of Sustainable Cities. Neoliberalism and Urban Strategies in Developing Countries. London: Zed Books.

Cooke, B. and Kothari, U. (eds.) (2001). Participation: the new tyranny? London: Zed Books.

Cornwall, A. (2002). Locating Citizen Participation. IDS Bulletin, 33(2), 49-58.

De Carli, B. and Frediani, A. A. (2016). Insurgent regeneration: spatial practices of citizenship in the rehabilitation of inner city São Paulo. GeoHumanities, 2 (2), 331-353.

Fainstein, S. (1999). 'Can we make the cities we want?', in R. A. Beauregard and S. Body-Gendrot, The urban moment: cosmopolitan essays on the late-20thcentury city, London: Sage Publications, pp: 249272.

Flyvbjerg, B. (1996). The Dark Side of Planning: Rationality and "Realrationalität", Explorations in Planning Theory, (May), 383-394.

Frediani, A.A. (2016). Re-imagining Participatory Design: Reflecting on the ASF-UK Change by Design Methodology. Design Issues, 32(3), 98-111.

Frediani, A. A., Walker, J. and Butcher, S. (eds.) (2014a). Participatory Informal Settlement Upgrading and Well-being in Kisumu, Kenya: MSc Social Development Practice Student Report. London: The Bartlett Development Planning Unit. Retrieved from: http://www.bartlett.ucl. ac.uk/dpu/programmes/postgraduate/msc-socialdevelopment-practice/Overseas-fieldwork

Frediani, A. A., Walker, J. and Hirst, L. (eds.) (2014b). Democratising the City: The Role of Neighbourhood Planning in Expanding Participatory Capabilities of the Urban Poor: MSc Social Development Practice Student Report. London: The Bartlett Development Planning Unit. Retrieved from: http://www.bartlett. ucl.ac.uk/dpu/programmes/postgraduate/msc-socialdevelopment-practice/Overseas-fieldwork

Frediani, A. A. and Monson, T. (eds.) (2016). Advocating for People-Centred Development in Kisumu, Kenya: MSc Social Development Practice Student Report. London: The Bartlett Development Planning Unit. Retrieved from http://www. bartlett.ucl.ac.uk/dpu/programmes/postgraduate/ msc-social-development-practice/Overseasfieldwork

Frediain, A.A., Macfarlane, A., Boni, A. and Maki, A. (2018). The role of video-making in expanding participatory capabilities of the urban poor. Research Report. The Bartlett Development Planning Unit, University College London.

Frediani, A.A., De Carli, B., Barbosa, B.R., Comarú, F.A. and Moretti, R. S. (2019). São Paulo: A pedagogy of confrontation. Informal building occupations in São Paulo's central neighbourhoods. In R. Rocco, \& J. van Ballegooijen (Eds.), Routledge Handbook on Informal Urbanisation. Abingdon: Routledge.

González, G. (2013). Una Historia de FUCVAM. Montevideo: Ediciones Trilce.

Gualini, E. (ed.) (2015). Planning and Conflict: Critical Perspectives in Contentious Urban Developments. Abingdon: Routledge.

Gunder, M. (2003). Passionate planning for the others' desire: An agonistic response to the dark side of planning, Progress in Planning, 60(3), 235-319. doi: 10.1016/S0305-9006(02)00115-0.

Hamdi, N. (1995) Housing Without Houses: Participation, Flexibility, Enablement. London: Intermediate Technology Publications Ltd.

Harrison, P. (2006). On the Edge of Reason: Planning and Urban Futures in Africa, Urban Studies, 43(2), 319-335.

Harvey, D. (1982) The Limits to Capital. Oxford: Basil Blackwell.

Harvey, D. (2008). The Right to the city. New left review, 35, 23-40.

Hasan, A. (2006). Orangi Pilot Project: the expansion of work beyond Orangi and the mapping of informal settlements and infrastructure. Environment \& Urbanization, Vol 18(2), 451-480. DOI: 10.1177/0956247D8o0w6n0lo6a9de6d2

hooks, b. (1991). Yearning: race, gender, and cultural politics. Turnaround, London.

Housing and Land Rights Network (HLRN) and Amel Association International (2018). Right to the City in Greater Beirut: Context Assessment in Light of the Refugee and Displacement Crisis. Housing and Land Rights Network, Cairo.

Huchzermeyer, M. (2014). Invoking Lefebvre's 'right to the city' in South Africa today: A response to Walsh, City, 18:1, 41-49, DOI: 10.1080/13604813.2014.868166

Huxley, M. and Yiftachel, O. (2000). New Paradigm or Old Myopia? Unsettling the Communicative Turn in Planning Theory, Journal of Planning Education and Research, 19, 333-342. doi: 10.1177/0739456X0001900402. 
Jakob, E. (2003). Stones in the Way on Selfdetermination in Housing in Times of Globalisation. Social Production of Habitat in Latin America. Trialog, 78(3), 5-7.

Kiefer, K. and Ranganathan, M. (2018). The Politics of Participation in Cape Town's Slum Upgrading: The Role of Productive Tension, Journal of Planning Education and Research, 1-15.

Larraín, B. (2019). Social Production of Habitat as a tool for advocacy in an African context? The case of Mashimoni, Nairobi. DPU Policy Brief from MSc Dissertation, January 2019, The Bartlett Development Planning Unit, UCL.

Lefebvre, H. (1991). The Production of Space. Oxford: Wiley-Blackwell.

Legacy, C. (2017). Is there a crisis of participatory planning? Planning Theory, 16(4), 425-442.

Lemanski, C. (2011). Moving up the ladder or stuck on the bottom rung? Homeownership as a solution to poverty in urban South Africa. International Journal of Urban and Regional Research, 35, 57-77.

Macarthy, J., Frediani, A. A., Kamara, S. F. (2019). Report on the role of Community Action Area Planning in expanding participatory capabilities of the urban poor. Freetown: Sierra Leone Urban Research Centre.

Madanipour, A. (2007) Social exclusion and space, in: Stout F. and LeGates, R. T. (eds.), The City Reader. London: Routledge, pp. 158-165.

Miessen, M. (2010). The Nightmare of Participation. Sternberg Press, Berlin.

Miraftab, F. (2009). Insurgent Planning: Situating Radical Planning in the Global South. Planning Theory, vol. 8(1), 32-50.

Miraftab, F. (2018). Insurgent Practices and Decolonization of Future(s) in Gunder, M., Madanipous, A. and Watson, V. (eds.) The Routledge Handbook of Planning Theory. Abingdon: Routledge. Chapter 22, pp. 276-288.

Mitlin, D. and Patel, S. (2005). Re-interpreting the rights-based approach - a grassroots perspective on rights and development. Global Poverty Research Group - Working Paper Series, 022.

Mouat, C., Legacy, C. and March, A. (2013). The Problem is the Solution: Testing Agonistic Theory's Potential to Recast Intractable Planning Disputes, Urban Policy and Research, 31(2), 150-166. doi: 10.1080/08111146.2013.776496.

Natarajan, L. (2017). Socio-spatial learning: A case study of community knowledge in participatory spatial planning, Progress in Planning, 111, 1-23.

Ortiz, E. (2007). Integración de un sistema de instrumentos de apoyo a la producción social de vivienda. Coalición internacional para el hábitat (hic-al), Colombia.

Ortiz, E. and Zárate, L. (2004) De la marginación a la ciudadania: 38 casos de producción y gestión social del hábitat. Diálogos Ciudad y Ciudadanos del siglo XXI: Coalición Internacional para el Hábitat.

Purcell, M. (2006). Urban Democracy and the Local Trap. Urban Studies, 43(11), 1921-1941.

Rigon, A. (2017). Intra-settlement politics and conflict in enumerations. Environment and Urbanization, 29(2), 581-596.

Romero, G. (2003) Social Production of Habitat: Reflections on its History, Conceptions and Proposals. Social Production of Habitat in Latin America. Trialog, 78(3), 8-15.

Roy, A. (2009). Why India Cannot Plan Its Cities: Informality, Insurgence and the Idiom of Urbanization. Planning Theory, 8(1), 76-87.

Santos, M. (1979). The Shared Space, the two circuits of the urban economy in underdeveloped countries. London and New York: Methuen.

Storper, M. (2003) The Poverty of Radical Theory Today: From the False Promises of Marxism to the Mirage of the Cultural Turn, International Journal of Urban and Regional Research, 25(1), 155-179. doi: 10.1111/1468-2427.00303.

Swyngedouw, E. (2011). Designing the Post-Political City and the Insurgent Polis. London: Bedford Press.

Thorpe, A. (2017). Rethinking Participation, Rethinking Planning, Planning Theory \& Practice, 18:4, 566-582.

Walker, J. and Butcher, S. (2016). Beyond onedimensional representation: challenges for neighbourhood planning in socially diverse urban settlements in Kisumu, Kenya. International Development Planning Review, 38(3), 275-295.

Watson, V. (2002). The usefulness of normative planning theories in the context of Sub-Saharan Africa, Planning Theory, 1(1), 27-52.

Watson, V. (2014). Co-production and collaboration in planning - The difference, Planning Theory \& Practice, 15(1), 62-76.

Yacobi, H. (2007) The NGOization of space: dilemmas of social change, planning policy, and the Israeli public sphere, Environment and Planning D: Society and Space, 25, 745-758

Yacobi, H. (2012). Borders, Boundaries and Frontiers: Notes on Jerusalem's Present Geopolitics. Eurasia Border Review, 3(2), 55-69.

Yacobi, H. and Cociña, C. (2018). Jerusalem: Planning in the face of political conflict. DPU SummerLab, 2017 series, 8-11. Retrieved from https://www.ucl. ac.uk/bartlett/development/sites/bartlett/files/ summerlab_2017_publication.pdf

Yamamoto, A. D. (2017). Why agonistic planning? 
Questioning Chantal Mouffe's thesis of the ontological primacy of the political,Planning Theory, 16(4),384-403. doi: 10.1177/1473095216654941.

Yiftachel, O. (1998). Planning and Social Control: Exploring the 'Dark Side'. Journal of Planning Literature, 12(2), 395-406.

Yiftachel, O. and Yacobi, H. (2002). Planning a Bi-National Capital: Should Jerusalem Remain United? Geoforum, 33, 137-45.

Zárate, L. (2018). Social Production of Habitat lessons from Latin America. Development Workshop. Online Resource: http://www.dw.angonet.org/ forumitem/lorena-zarate-social-productionhabitat-lessons-latin-america.

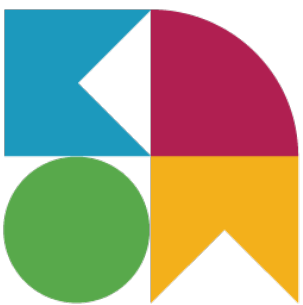

